\title{
Around the world in 17 days - hemispheric-scale transport of forest fire smoke from Russia in May 2003
}

\author{
R. Damoah ${ }^{1}$, N. Spichtinger ${ }^{1}$, C. Forster ${ }^{1}$, P. James ${ }^{1}$, I. Mattis ${ }^{2}$, U. Wandinger ${ }^{2}$, S. Beirle ${ }^{3}$, T. Wagner ${ }^{3}$, and A. Stohl ${ }^{4}$ \\ ${ }^{1}$ Department of Ecology, Technical University of Munich, Freising, Germany \\ ${ }^{2}$ Institute for Tropospheric Research, Leipzig, Germany \\ ${ }^{3}$ Institute for Environmental Physics, University of Heidelberg, Heidelberg, Germany \\ ${ }^{4}$ Cooperative Inst. for Research in Environmental Science, Univ. of Colorado/NOAA Aeronomy Laboratory, Boulder, USA
}

Received: 14 January 2004 - Published in Atmos. Chem. Phys. Discuss.: 15 March 2004

Revised: 9 June 2004 - Accepted: 27 July 2004 - Published: 23 August 2004

\begin{abstract}
In May 2003, severe forest fires in southeast Russia resulted in smoke plumes extending widely across the Northern Hemisphere. This study combines satellite data from a variety of platforms (Moderate Resolution Imaging Spectroradiometer (MODIS), Sea-viewing Wide Field-ofview Sensor (SeaWiFS), Earth Probe Total Ozone Mapping Spectrometer (TOMS) and Global Ozone Monitoring Experiment (GOME)) and vertical aerosol profiles derived with Raman lidar measurements with results from a Lagrangian particle dispersion model to understand the transport processes that led to the large haze plumes observed over North America and Europe. The satellite images provided a unique opportunity for validating model simulations of tropospheric transport on a truly hemispheric scale. Transport of the smoke occurred in two directions: Smoke travelling northwestwards towards Scandinavia was lifted over the Urals and arrived over the Norwegian Sea. Smoke travelling eastwards to the Okhotsk Sea was also lifted, it then crossed the Bering Sea to Alaska from where it proceeded to Canada and was later even observed over Scandinavia and Eastern Europe on its way back to Russia. Not many events of this kind, if any, have been observed, documented and simulated with a transport model comprehensively. The total transport time was about 17 days. We compared transport model simulations using meteorological analysis data from both the European Centre for Medium-Range Weather Forecast (ECMWF) and the National Center for Environmental Prediction (NCEP) in order to find out how well this event could be simulated using these two datasets. Although differences between the two simulations are found on small scales, both agree remarkably well with each other and with the observations on large scales. On the basis of the available observations, it cannot be decided which simulation was more realistic.
\end{abstract}

Correspondence to: R. Damoah

(damoah@forst.tu-muenchen.de)

\section{Introduction}

About $85 \%$ of biomass burning takes place in the tropics (Andreae, 1991) and causes pollutant emissions that have a strong impact on the tropospheric chemistry (Galanter et al., 2000). Aerosols and trace gases such as carbon monoxide, nitrogen oxides and non-methane hydrocarbons from biomass burning play an important role for atmospheric chemistry and radiative properties of the atmosphere. Carbon monoxide, for instance, is involved in tropospheric ozone chemistry (Crutzen, 1973) and aerosols can be transported into the stratosphere (Fromm et al., 2000) where they may influence concentrations of stratospheric ozone through catalytic chemical reactions. Therefore changes in the concentrations of aerosols and carbon monoxide also affect ozone, which plays an important role in the global climate system (Daniel and Solomon, 1998; Logan et al., 1981). Furthermore, aerosols by themselves can strongly influence the radiation in the atmosphere (Christopher et al., 2000; Hsu et al., 1999) and represent the largest source of uncertainty in current climate model simulations (IPCC, 2001).

In addition to biomass burning in the tropics, fires in the boreal forest are a further strong emission source. Recently it was found that through long-range transport, emissions from boreal forest fires can affect the concentrations of many trace substances in distant regions. Wotawa and Trainer (2000) found that the high $\mathrm{CO}$ and $\mathrm{O}_{3}$ concentrations over southeastern United States in 1995 over a period of 2 weeks were caused by the transport of a pollution plume from Canadian fires and photochemical ozone formation in this plume, while long-range transport events of aerosols (Hsu et al., 1999; Formenti et al., 2002; Fiebig et al., 2002; Wandinger et al., 2002), $\mathrm{CO}$ and $\mathrm{O}_{3}$ (Forster et al., 2001) and $\mathrm{NO}_{\mathrm{x}}$ (Spichtinger et al., 2001) from Canadian forest fires have also been observed over Europe. According to model simulations, the time scale of intercontinental transport of pollutant emissions 
is on the order of 3-30 days (Stohl et al., 2002). The upper range of this estimate may be a typical time scale for the mixing of pollutants in the northern hemisphere middle latitudes. In case studies, Wotawa and Trainer (2000) reported a duration of about 2 weeks for the transport of Canadian fire emissions to the southeastern United States, Forster et al. (2001) quoted a period of about 1 week for the transport of Canadian fire emissions to Europe. Emissions from the fires can be transported upward in warm conveyor belts (WCBs) (Stohl, 2001) or by - sometimes extreme - convection (Fromm and Servranckx, 2003) into the upper troposphere where fast intercontinental transport may occur (Stohl and Trickl, 1999; Yienger et al., 2000; Stohl et al., 2002).

Fires in Canada have received much attention recently, whereas fires in Russia are much less well studied. The world's total closed boreal forest covers about 1 billion ha (29\% of the world's forest area), of which Russian boreal forests contribute about two thirds (Kasischke et al., 2000). Fire is a major natural disturbance in Russian forests because: (1) Boreal forests are dominated by coniferous stands of high fire hazard; (2) Considerable part of the forest territory is unmanaged and unprotected; (3) The forests contain large amounts of accumulated organic matter due to slow decomposition of plant material; and (4) most of the boreal regions have limited amounts of precipitation and long periods of drought in the fire season. Despite the large areas burning in Russian forests almost every year, until recently relatively little attention has been paid to fires there compared to Canadian fires. However, recently Siberian forest fires have been the subject of several studies (e.g. Yoshizumi et al., 2002; Conard et al., 2002; Kasischke and Bruhwiler, 2003, Shvidenko and Goldammer, 2001, Shvidenko and Nilsson, 2000).

A long-period (1970-1999) average estimate of burned areas for all Russian forests and tundra is $5.1 \times 10^{6} \mathrm{ha} \mathrm{yr}^{-1}$ (Shvidenko and Goldammer, 2001), Lavoue et al. (2000) gave an annual average of $4 \times 10^{6} \mathrm{ha} \mathrm{yr}^{-1}$ (1960-1997), but some other estimates are as high as $10-12 \times 10^{6} \mathrm{ha} \mathrm{yr}^{-1}$ (Conard and Ivanova, 1998; Valendik, 1996). In fact, recent estimates of the annual area burned in Russia vary considerably. Partly this is due to the large interannual variability and a strong increase in fire activity since the late 1990s. In 1987, when $14.5 \times 10^{6}$ ha of forest and other lands were destroyed was an extreme year. Assuming typical emission factors (Andreae and Merlet, 2001), this contributed about $20 \%$ of $\mathrm{CO}_{2}, 36 \%$ of $\mathrm{CO}$ and $69 \%$ of total $\mathrm{CH}_{4}$ produced by savanna burning during an average year (Cahoon et al., 1994). 1998 was another severe year when about $12 \times 10^{6}$ ha were destroyed according to recent estimates (Kasischke and Bruhwiler, 2003). It was even worse in the year 2003. The first fires were detected as early as April within the Trans-Baikal region. In May the situation in the south of Russia escalated. By the end of May, tens of thousands of fires had destroyed more than $15 \times 10^{6}$ ha of land in the Russian Federation. The most affected regions were Chitinskaya Oblast $\left(55-56^{\circ} \mathrm{N}\right.$, $\left.114-120^{\circ} \mathrm{E}\right)$, Buryatiya Repulic $\left(55-59^{\circ} \mathrm{N}, 107-114^{\circ} \mathrm{E}\right)$ and
Amurskaya Oblast $\left(52-56^{\circ} \mathrm{N}, 120-132^{\circ} \mathrm{E}\right)$ (GFMC, 2003). At the end of the 2003 fire season, more than $19 \times 10^{6}$ ha of land had been destroyed in Russia (Slightly less than the size of Iraq).

In this paper, we study a hemispheric-scale transport event in May 2003. Over a period of about 17 days, satellite images in several regions of the northern hemisphere show the transport around the world of smoke from the Siberian fires. Lidars in eastern Asia, North America and Europe (Mattis et al., 2003) took vertical profiles of the smoke. The transport model and data used in this paper are described in the following section. Results from the smoke transport simulations are presented in Sect. 3, together with discussions about the relevant meteorological aspects of the event, and conclusions are drawn in Sect. 4.

\section{Tools and methodology}

The GOME instrument has been operational aboard the ERS-2 satellite since April 1995. With a spectral range from $240 \mathrm{~nm}$ to $790 \mathrm{~nm}$, GOME measures the scattered and reflected sunlight from the surface using the nadir viewing mode. Operational data products of GOME result from radiance and solar irradiance spectra which are taken through several processing steps to obtain global distributions of total column amounts of $\mathrm{NO}_{2}$ and other species using the DOAS approach (Differential Optical Absorption Spectroscopy) (Platt, 1994). Tropospheric $\mathrm{NO}_{2}$ columns used in this study are derived from a stratosphere/troposphere separation algorithm (Beirle et al., 2003).

NASA's Moderate Resolution Imaging Spectroradiometer (MODIS) aboard the Terra and Aqua satellites measures radiances in 36 spectral bands, from which a large number of different products are derived. Of importance for this study are the locations of active fires (hot spots), burn scars and aerosols (including smoke from forest fires) (Chu et al., 2002; Remer et al., 2002; Kaufman et al., 1998a; Justice et al., 1996). Its main fire detection channels saturate at high brightness temperatures of $500 \mathrm{~K}$ at $4 \mu \mathrm{m}$ and $400 \mathrm{~K}$ at $11 \mu \mathrm{m}$.

Other platforms that observed the smoke were Total Ozone Mapping Spectrometer (TOMS) aboard the Earth Probe satellite which provides data on UV-absorbing tropospheric aerosols including smoke from biomass burning (Hsu et al., 1999). And the Sea-viewing Wide Field Sensor (Sea WiFS) (Hook et al., 1993) aboard the Sea Star spacecraft, which operates in 8 wavelength channels ranging from $403-887 \mathrm{~nm}$ but uses channels 765 and $865 \mathrm{~nm}$ for the estimation of aerosol radiance (Gordon and Wang, 1994).

The Raman lidar at Leipzig, Germany (Mattis et al., 2003) measured vertical smoke profiles in terms of volume extinction coefficients of aerosols at 355 and $532 \mathrm{~nm}$, and backscatter coefficients at 355,532 and $1064 \mathrm{~nm}$ wavelengths. 


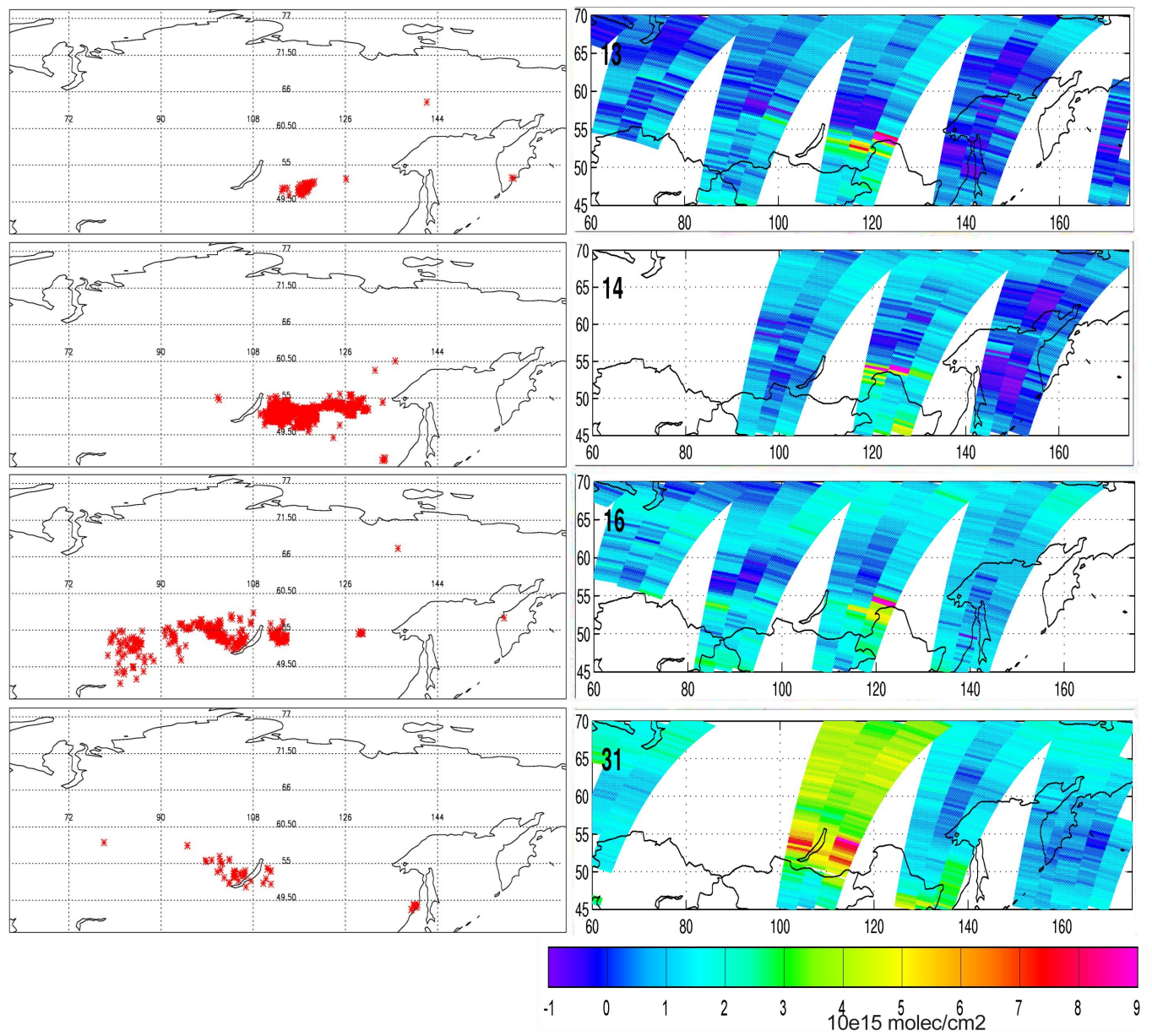

Fig. 1. MODIS fire product for 13,14, 16 and 31 May, 2003, respectively (left column) and corresponding daily GOME tropospheric $\mathrm{NO}_{2}$ (right column).

In order to determine the origin and the transport of these plumes, we used the Lagrangian particle dispersion model FLEXPART (Stohl et al., 1998; Stohl and Thomson, 1999) to simulate the transport of a CO tracer. A CO tracer was used because $\mathrm{CO}$ has a relatively long life time that ranges from 1 month (in the tropics) to 4 months (in the mid-latitudes) (Seinfeld and Pandis, 1998). As the emphasis in this paper is on the transport, we used a passive tracer (CO) not undergoing removal processes so that observed structures will always be present in the model results for qualitative comparison.

FLEXPART simulates the long-range transport, diffusion, dry and wet deposition and radioactive decay of air pollutants released from point, line or volume sources. It treats advection and turbulent diffusion by calculating the trajectories of a multitude of particles. Stochastic fluctuations, obtained by solving Langevin equations (Stohl and Thomson, 1999), are superimposed on the grid-scale winds from global meteorological datasets to represent transport by turbulent eddies, which are not resolved. Global data sets also do not resolve individual convective cells, although they reproduce the large-scale effects of convection (e.g. the strong ascent within WCBs ). Therefore, FLEXPART has recently been equipped with a convection scheme (Emanuel and ZivkovicRothman, 1999) to account for sub-grid scale transport. FLEXPART can be driven by meteorological analysis data either from the European Centre for Medium-Range Weather Forecasts (ECMWF, 1995) or from the Global Forecast System (GFS) of the National Center for Environmental Prediction (NCEP). Simulations using data from both sources were made in order to possibly find out which dataset provided a more accurate simulation of the transport event.

The ECMWF model version used here has 60 hybrid model levels in the vertical, while the GFS output is available on 26 pressure levels. In the horizontal, both datasets are global with a $1^{\circ} \times 1^{\circ}$ regular grid. 6-hourly analyses are supplemented by 3-hour forecast step data to provide a 3hourly temporal resolution in both cases. An output grid with a $1^{\circ} \times 2^{\circ}$ latitude/longitude resolution, a vertical spacing of $1000 \mathrm{~m}$ and an output interval of $3 \mathrm{~h}$ was employed. Due to the significantly higher vertical resolution of the ECMWF 


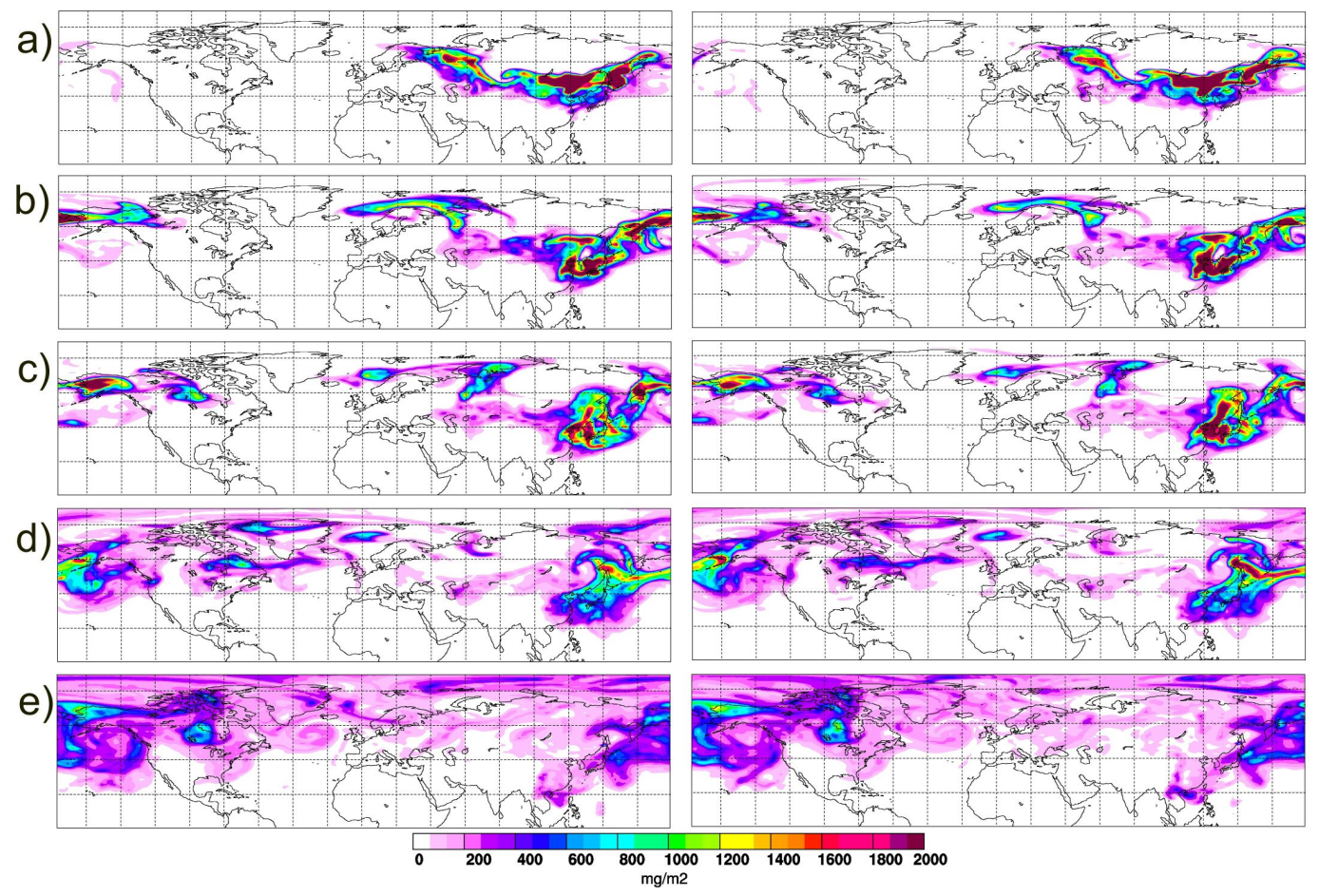

Fig. 2. Total CO tracer columns from simulations using ECMWF data (left column) and GFS data (right columns) on (a) 18 May 2003 at 00 UTC, (b) 21 May at 00 UTC, (c) 22 May at 06 UTC, (d) 26 May at 06 UTC and (e) 31 May at 00 UTC, respectively.

data grid and the higher intrinsic horizontal resolution of the operational ECMWF forecast model, compared to the GFS model, the simulation based on ECMWF data is our primary simulation of the smoke transport and will be used to highlight specific transport phenomena. However, the GFS simulation is very useful as a control run to indicate how differences in the meteorological analyses might affect the accuracy of the transport and its comparison with satellite data.

In the tracer simulations, $5 \times 10^{6}$ particles were released to calculate the transport of $\mathrm{CO}$ emissions from fires in Russia. For our simulation we considered the 3-week period from 10 to 31 May 2003, when the most spectacular long-range transport event occurred. Between 10 and 31 May, with approximately $0.26 \times 10^{6}$ ha burning per day, a total area of about $5.5 \times 10^{6}$ ha was burned in Chitinskaya Oblast, Buryatiya Repulic and Amurskaya Oblast, according to weekly estimates of the Global Fire Monitoring Center (GFMC, 2003). In order to describe the regional and daily variations of the fires, the MODIS hot spot data (MOD14 product) were used to spatially and temporally disaggregate the total burned area taken from GFMC (2003), assuming that the 10310 hot spots detected during that period (Fig. 1) all burned an equal area. $\mathrm{CO}$ emissions were taken to be proportional to the area burned. Assuming a CO release of $4500 \mathrm{~kg}$ per hectare of forest burned, which is similar to recent estimates based on emissions from the Canadian Northwest Territories (Cofer et al., 1998), we estimate that $24.75 \mathrm{Tg}$ of $\mathrm{CO}$ were released into the atmosphere due to the burning during May 10 to May 31 2003. The altitudes at which the emissions were effectively released into the atmosphere vary from day to day and are actually not known. Lacking this information, we released the $\mathrm{CO}$ tracer into the lowest $3 \mathrm{~km}$ of the model atmosphere. Sensitivity studies performed on this event by varying the upper release level from $0.5 \mathrm{~km}$ to $4 \mathrm{~km}$ altitude did not change the results much (less than $4 \%$ of the global mean concentration).

\section{Results}

The left column of Fig. 1 shows Moderate-Resolution Imaging Spectroradiometer (MODIS) fire products (MOD14) for 13, 14, 16 and 31 May, 2003, respectively. At the example of these four days it can be seen that there is a relatively high day-to-day variability, which to some extent may be real, but partly may also be due to the presence or non-presence of clouds and/or smoke over the fires. Because we have used the hot spot data to estimate the emissions in our model this may also introduce artificial variability into the transport model simulations. At the locations of these fires, distinct maxima of GOME's $\mathrm{NO}_{2}$ tropospheric columns are found (right column). Despite the general agreement between fire locations and $\mathrm{NO}_{2}$ maxima, the number of the fires does not correlate well to the strength of the $\mathrm{NO}_{2}$ signal. For instance, on 14 May, the hot spots show a strong burning east of Lake Baikal 
a)

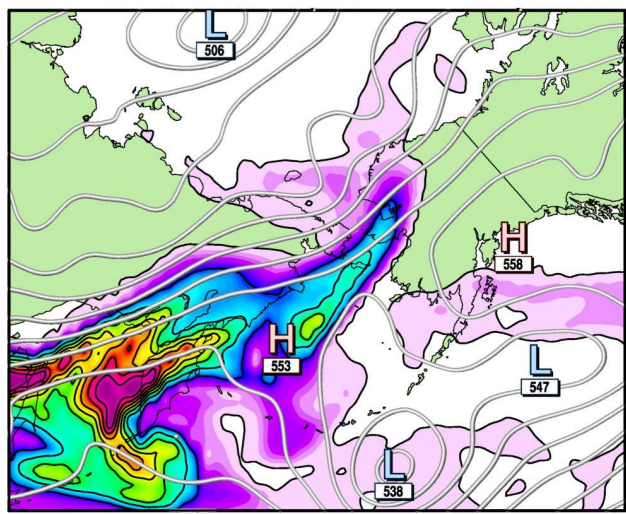

c)

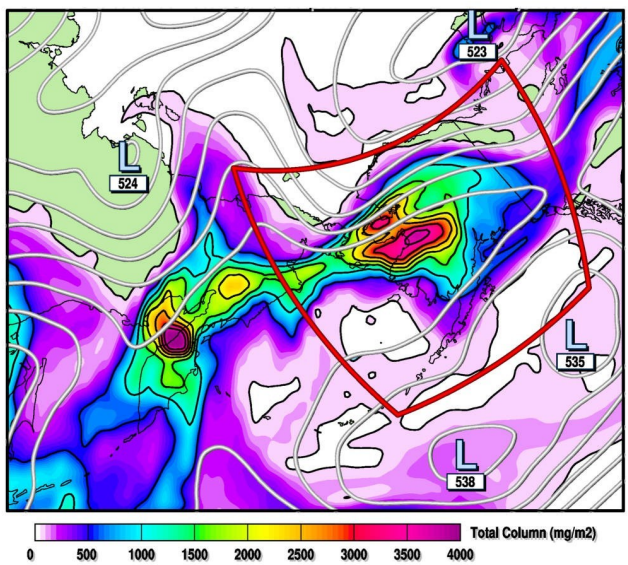

b)

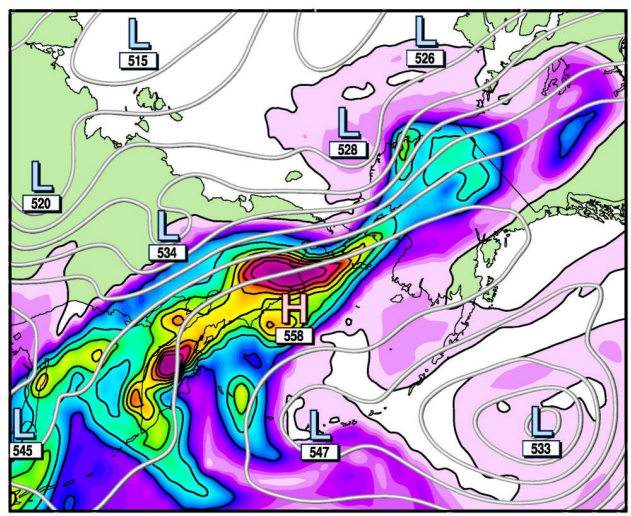

d)

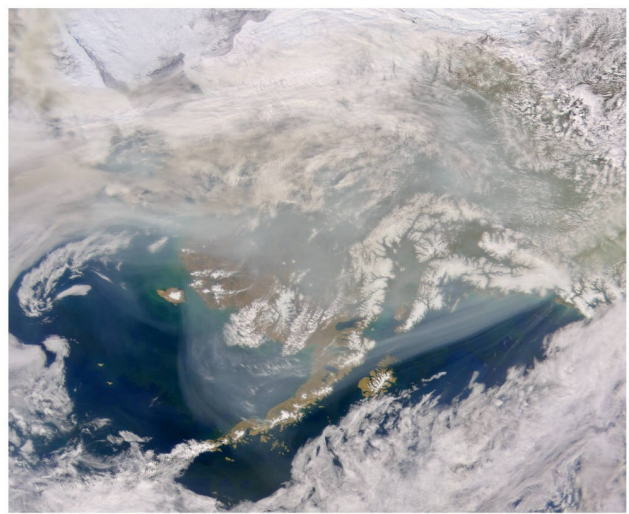

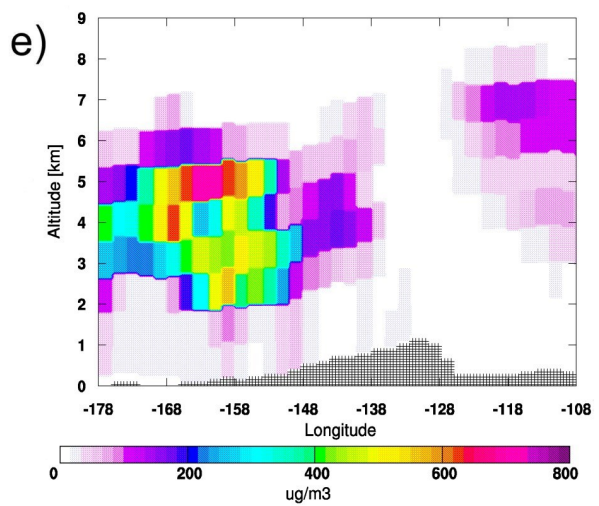

Fig. 3. (a-c) FLEXPART ECMWF CO tracer columns over the Bering Sea and adjacent regions with superimposed contours of the $500 \mathrm{hPa}$ geopotential surface, based on GFS analyses, contour interval 5 dam, at (a) 19 May 00 UTC, (b) 20 May 12 UTC and (c) 22 May 00 UTC; The hatched area represents the topography. Green areas represent land surface, oceans are white. The red rectangle in c) shows approximately the area shown in panel d); (d) SeaWiFS image showing smoke over Alaska at 23 UTC on 21 May; Whitish colors are snow, ice and clouds, whereas the blue-grey indicate smoke. (e) vertical section through the FLEXPART CO tracer at $64^{\circ}$ latitude on 22 May at 00 UTC using ECMWF data.

but relatively low $\mathrm{NO}_{2}$ columns were observed over the fires by GOME. On the other hand, fewer hot spots were detected east of Lake Baikal on 13 and 31 May, but the GOME $\mathrm{NO}_{2}$ enhancements over the fires were much larger. This may be due to the presence of clouds which hamper both the detection of hot spots and $\mathrm{NO}_{2}$ beneath the clouds, differences in the temporal coverage of the two intstruments, or may reflect true variability of the $\mathrm{NO}_{2}$ emissions (for instance, different emissions strengths during flaming versus smoldering burning condition) and their transport away from their sources.

Before considering the specific meteorological events which were significant for the intercontinental transport of aerosols from the Russian fires, it is worthwhile looking at the spread of the pollution with time over the hemisphere. 
Figure 2 shows total columns of the $\mathrm{CO}$ tracer simulated by FLEXPART using ECMWF (left column) and GFS (right column) data as input. At around 18 May (Fig. 2a), there were two main modes of transport, one northwestwards towards Northern Europe and the other eastwards to the Okhotsk Sea. The CO tracer travelling towards Europe was lifted over the Urals and was heading to Scandinavia (Fig. 2a). Four days later it split up over the Norwegian Sea with one part reversing to Asia (Fig. 2c). The more interesting to us is the other mode of the transport, which took the fire emissions around the globe. The CO tracer was lifted over the Okhotsk Sea, where it travelled rapidly through Alaska (Fig. 2b) to Canada (Fig. 2c), then crossed the Atlantic to Europe (Fig. 2d) where it began to merge with the tracer which had been advected directly out of Russia from the east. On 31 May, 2003 the CO tracer could be seen over much of the northern hemisphere (Fig. 2e). By this time the plume that had travelled across the Pacific and Atlantic oceans had also indeed crossed Eurasia, taking about 17 days to circle the entire globe. A closer look at the two data sets reveals regional differences between simulations using ECMWF and GFS data, respectively. Generally, however, the two simulations were remarkably similar to each other. Both showed the two modes of transport and the hemispheric-scale transport event.

\subsection{Smoke over Alaska (8th day)}

During the period 19-22 May, the north Pacific jet was split into two components: a southern component near $40^{\circ} \mathrm{N}$ associated with the north Pacific storm track, not relevant to this discussion, and a zonally elongated polar jet component stretching from north-east Siberia across the Bering Sea into Alaska; the latter is shown at $500 \mathrm{hPa}$ in Figs. 3a-c. A large body of tracer was advected out of Siberia by this strong westerly flow which was further intensified by the growth of two synoptic waves on the jet, which cross the Bering Strait within $36 \mathrm{~h}$ of each other (Figs. $3 \mathrm{~b}$ and c). The first of these waves cuts off the leading edge of the plume which is then advected quickly into northwestern Canada. The main body of the plume is pushed by the second wave over Alaska and has been very well simulated by the FLEXPART CO tracer using both ECMWF (Fig. 3c) and GFS data (not shown). On 21 May 2003, Sea WiFS captured an aerosol plume (Fig. 3d) over Alaska that was presumably transported from the intense forest fire burning in Russia. Images from the MOPITT (Measurement Of Pollution In The Troposphere) instrument (not shown) studied within this period also shows forest fire emissions (Edwards et al., 2003) over Alaska. When comparing this available satellite image. In particular, the sharp edges of the plume in the image over the Gulf of Alaska, westwards to the Aleutians and then northwards over the Bering Sea, coincide well with the edges of the CO tracer plume. A vertical section through the FLEXPART-ECMWF $\mathrm{CO}$ tracer at $64^{\circ} \mathrm{N}$ indicates that the main plume over Alaska is concentrated between 2 and $5 \mathrm{~km}$ altitude while the advanced plume over northwestern Canada is somewhat higher, primarily lying between 4 and $7 \mathrm{~km}$. Clouds in Fig. $3 \mathrm{~d}$ are mostly at lower altitudes, partly lying underneath the smoke.

\subsection{Smoke over Canada (11th day)}

On 21 May a smoke plume which arrived first over north-western Canada (see description above) was advected quickly south-eastwards before arriving and becoming slowmoving near the Great Lakes in a diffluent mid-tropospheric flow on 23 May. On 24 May 2003 (Fig. 4c) simulated FLEXPART CO tracer showed elongated plumes which stretches from the north-western edge of Lake Superior up towards James Bay and reaches across to Quebec and the St. Lawrence River. The plume coincides well with the image of MODIS instrument aboard the Terra satellite which also showed elongated smoke plumes (Figs. 4a and b) on 23 and 24 May. An anticyclonic ridge builds between the polar cylconic vortex and a small new cut-off low which develops quickly to the south of the Great Lakes. As a result, the plume is stretched out and its western flank is advected around the developing low south- and eastwards into the eastern United States. Meanwhile its eastern flank is pulled out by strong westerly winds past the southern tip of Greenland and reaches Iceland by 24 May (Figs. $4 \mathrm{c}$ and d).

Another smoke maximum is indicated over part of Manitoba on 23 May in the upper left corner of Fig. 4a. This is the edge of the main plume body which was seen over Alaska on 22 May (Fig. 3c) and moved into Canada about $48 \mathrm{~h}$ behind the leading plume above. This large main plume is advected in the strong westerly flow and arrives over the Hudson Bay on 25 May, where much of it slows down as it comes under the influence of diffluent flow ahead of a developing ridge. The leading edge of this plume, however, is pulled away from the rest in two bursts by strong flow on the edge of a trough centred over Baffin Island. One part is advected northwards to western Greenland on 24 May (Fig. 4d) and another over the Labrador Sea on 25 May (Fig. 4e).

Figure $4 \mathrm{f}$ shows the TOMS aerosol index on 24 May. It also shows a maximum over Hudson Bay and a filament stretching from south-east of James Bay to the St. Lawrence river, in fairly good agreement with the FLEXPART tracer simulation. However, no significant aerosols registered in TOMS near Lake Superior. This can be partly attributed to the dissipation of the smoke in this region later on 24 May (note that local midday, significant for TOMS measurements, was after 18 UTC) or the possible presence of clouds.

\subsection{Smoke over Scandinavia (14th day)}

The rapid advection of the plume across the Atlantic was caused by the development of a small but intense and mobile synoptic wave and associated strong winds near Iceland on 25 May (Fig. 5a). This wave moves quickly eastwards 
a)

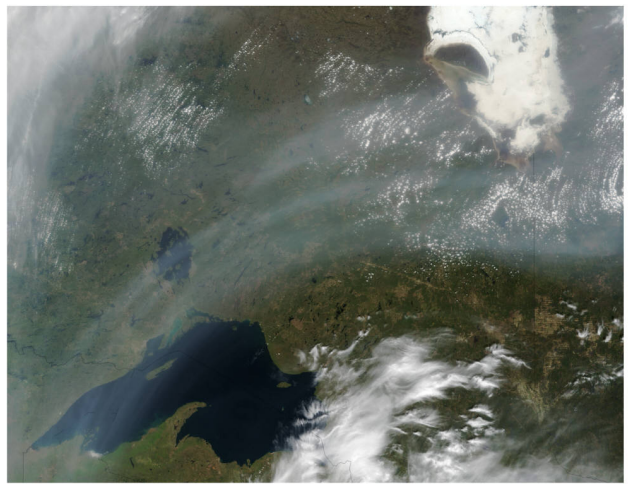

c)

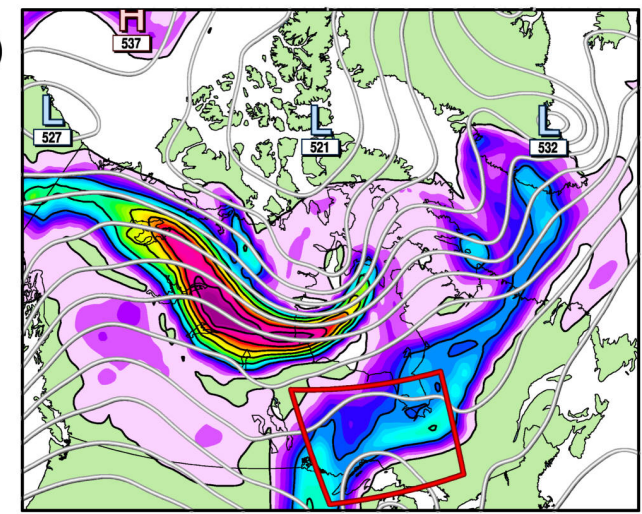

e)

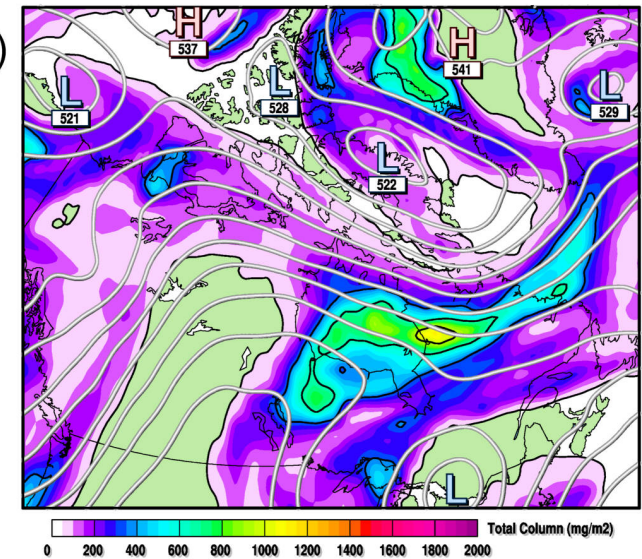

b)

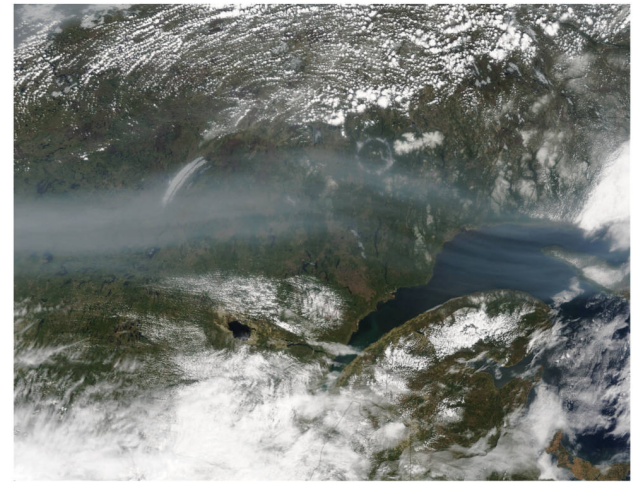

d)

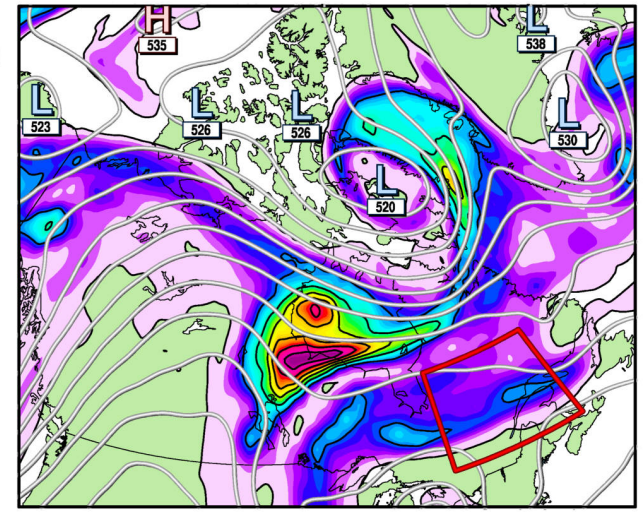

f)

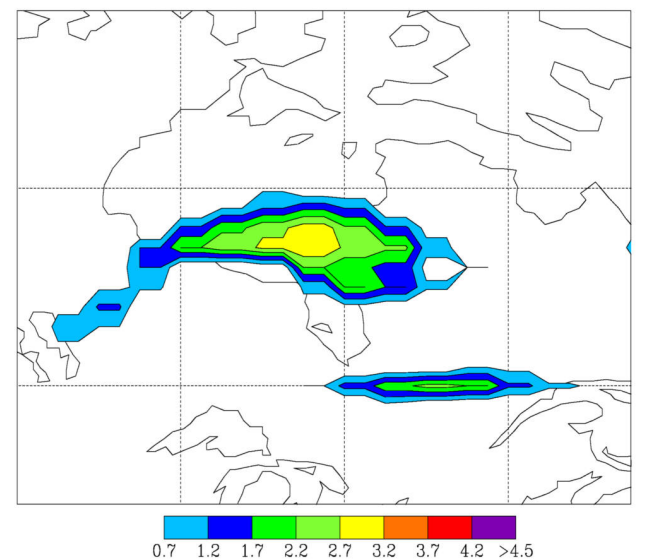

Fig. 4. MODIS Terra satellite images over (a) central Canada at 16:30 UTC, 23 May and (b) eastern Canada at 15:35 UTC, 24 May; (ce) FLEXPART ECMWF CO tracer columns over Canada with superimposed contours of the $500 \mathrm{hPa}$ geopotential surface, based on GFS analyses, contour interval 5 dam, at (c) 23 May 18 UTC, (d) 24 May 18 UTC and (e) 25 May 18 UTC; (f) TOMS aerosol index over eastern Canada on 24 May, 2003.

and is followed by an increasingly zonal flow which advects the remains of the plumes which had been over south-eastern Canada in streams across the Atlantic. FLEXPART simulations with both ECMWF (Fig. 5c) and GFS data (not shown), both of which showed CO tracer over parts of the North Atlantic, Scandinavia and the Baltic Sea. It also show tracer maxima at altitudes of about $5 \mathrm{~km}$ (Fig. 5e) The haze plume formed a curve from just to the south of Iceland down across to southern Norway and south-central Sweden and back up across western and central Finland. Further filaments are in evidence across the Skagerrak Strait near Denmark and over parts of the Baltic Sea, while further regions of haze plume are over parts of the European mainland, notably over Latvia, Lithuania and Poland.

The primary plume curve has been very well captured by the SeaWiFS sensor On 27 May 2003 (Fig. 5a). The positions of the maxima over southern Norway and western Finland have been well captured, although the leading edge of the smoke appears in the satellite image to have reached slightly further east over Finland than in the simulation. The 
a)

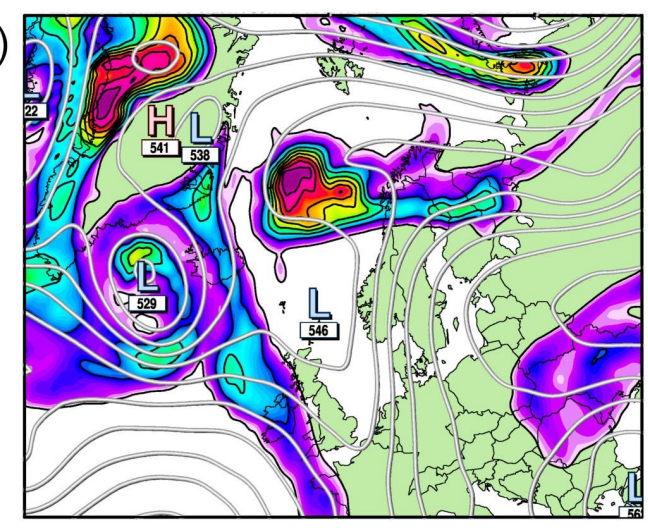

c)
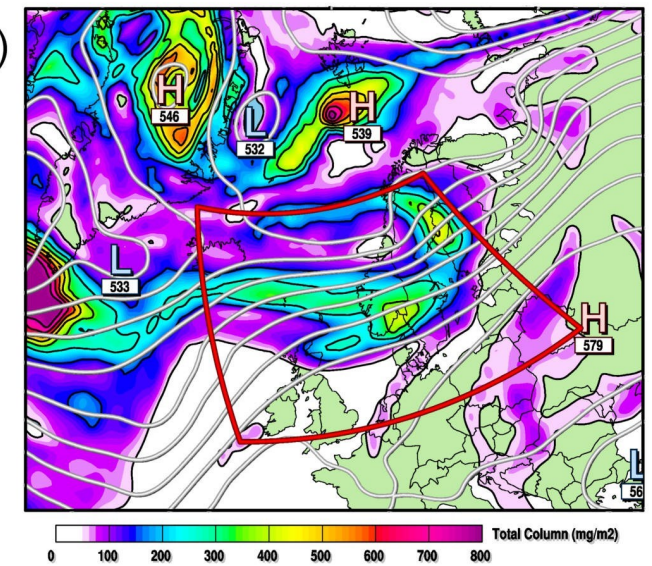

e)

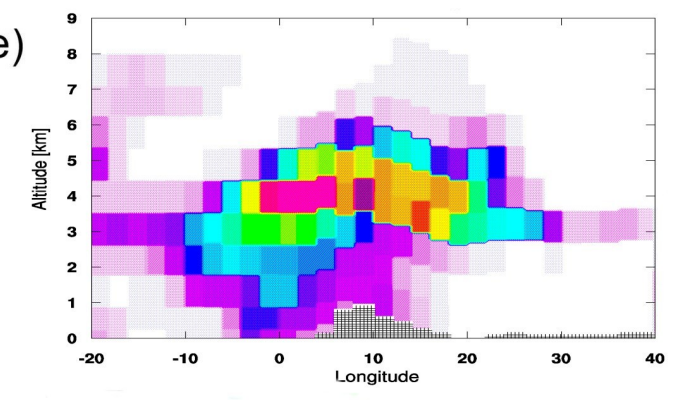

b)

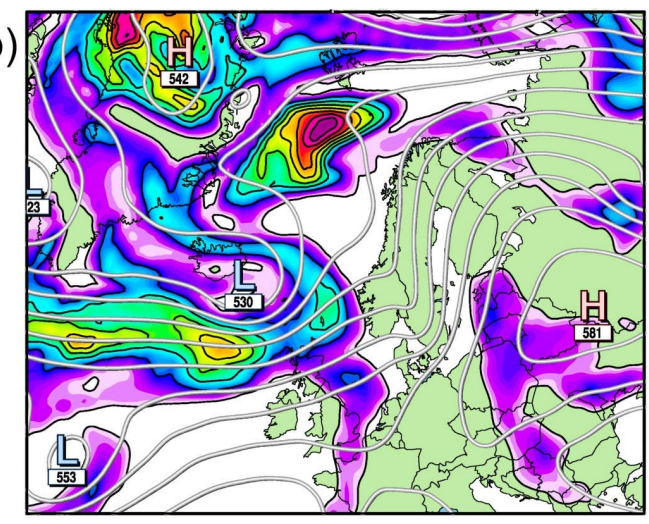

d)

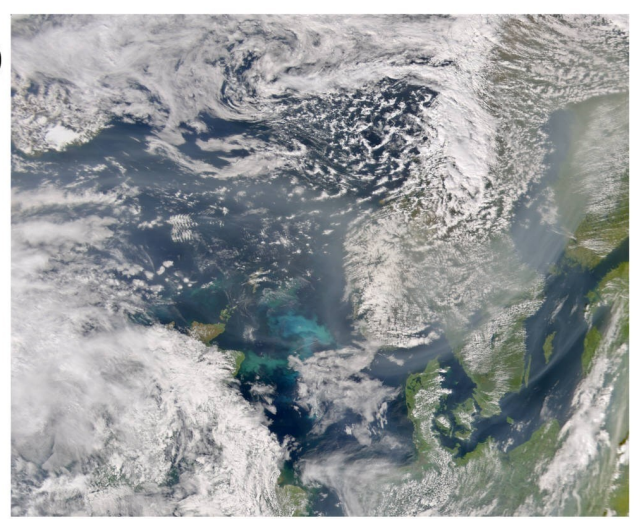

f)

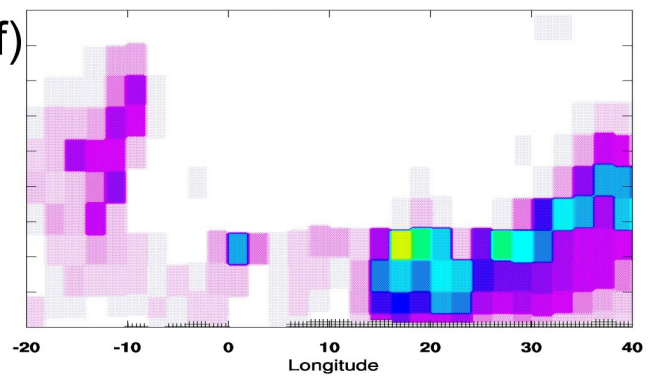

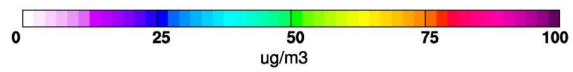

Fig. 5. (a-c) FLEXPART ECMWF CO tracer columns over the north-east Atlantic, Europe and Greenland with superimposed contours of the $500 \mathrm{hPa}$ geopotential surface, based on GFS analyses, contour interval 5 dam, at (a) 25 May 15 UTC, (b) 26 May 15 UTC and (c) 27 May 15 UTC; (d) Image of SeaWiFS sensor showing smoke over Scandinavia on 27 May, 2003 at 12:54 UTC. (e) and (f) vertical section through the FLEXPART CO tracer at $61^{\circ}$ latitude on 27 May at 15 UTC and $51^{\circ}$ latitude on 29 May at 21 UTC, respectively, using ECMWF data.

maximum over southern Norway corresponds to the component which had been advected over Labrador Sea on 25 May (Fig. 4e) while the maximum over western Finland contains smoke which had been the first to reach the Iceland region on 24 May (Fig. 4d).

The smoke thus arriving over Europe on 27 May had almost completed a loop around the globe and was heading back towards the source region in Russia. It also began inevitably to merge with smoke plumes which had been ad- vected directly from the east out of Russia. The large maximum near Jan Mayen, north-east of Iceland, on 25 May (Fig. 5a) had been advected slowly across northern Scandinavia during the previous days and became stagnant in a region of light mid-tropospheric winds in an anticyclonic ridge. Similarly, the CO tracer plume over Eastern Europe (Fig. 5ac) was advected slowly from the east in anticyclonic conditions and corresponds well with the observed haze plumes in this region. 
a)

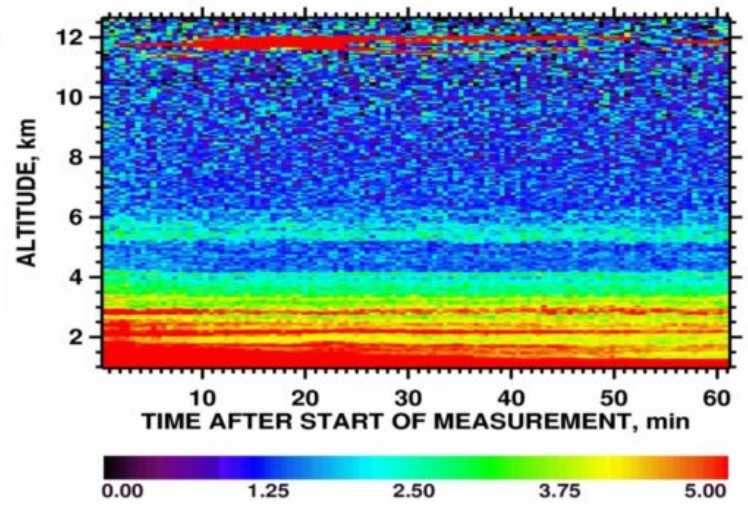

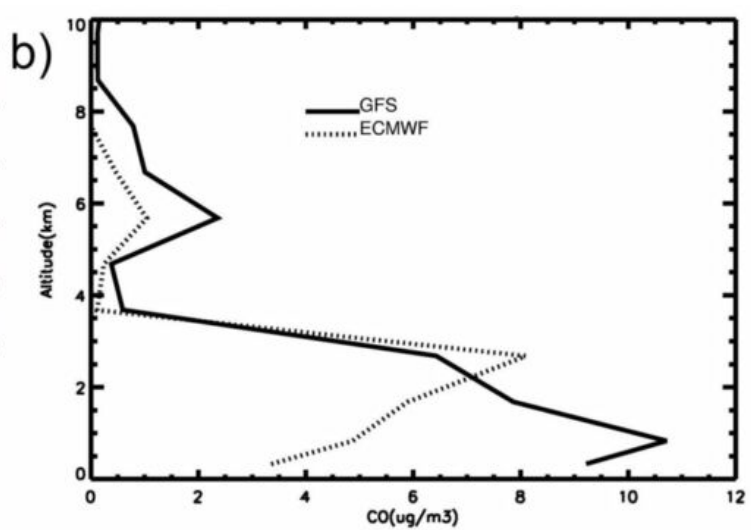

(C)
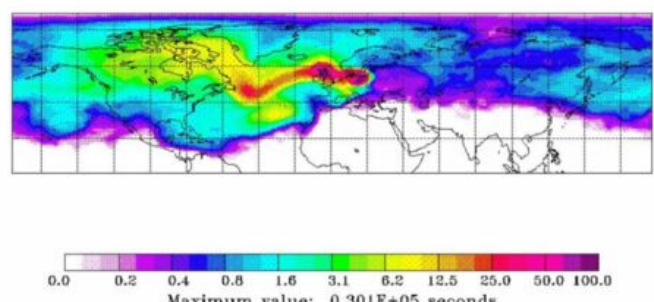

Fig. 6. (a) Lidar time-height plot of particle backscatter ratio at $1064 \mathrm{~nm}$ over Leipzig, Germany on 29 May, 2003 from 20 UTC to 21 UTC. The vertical and temporal resolutions are $60 \mathrm{~m}$ and $30 \mathrm{~s}$, respectively. (b) ECMWF (dotted line) and GFS (solid line) FLEXPART simulation profiles over Leipzig averaged between 18 and 21 UTC of 29 May, 2003. (c) Total column residence time of 50000 particles from a 20 days FLEXPART backward simulation starting at Leipzig on 29 May, 2003 at 21 UTC. The scale is in percentage of the maximum residence time given below the panel.

\subsection{Smoke over Germany (16th day)}

During the two days following 27 May, the smoke maximum over southern Norway was dissipated by diffluent flow on the edge of a strong ridge building to the south-west. Parts of the plume encroached on eastern Germany and continued to merge with the remnants of the eastern European plume which had been advected directly out of Russia. Observations from the Raman lidar at Leipzig, Germany on 29 May $\left(51.35^{\circ} \mathrm{N}, 12.43^{\circ} \mathrm{E}, 92 \mathrm{~m}\right)$ recorded particle extinction coefficients of $5-30 \mathrm{Mm}^{-1}$ and particle optical depths of $0.03-$ 0.12 at UV and visible wavelengths in the free troposphere from May to July 2003. Such unusually high aerosol levels had never been observed previously since the start of the measurements in 1997 (Mattis et al., 2003) as part of the European Aerosol Research Lidar Network (EARLINET). Lidar measurements from the German aerosol lidar network has been used to observe Canadian forest fire emissions over Germany (Forster et al., 2001). Figure 6a shows a strong lidar backscatter ratio of aerosol at $1064 \mathrm{~nm}$ without any separation between the boundary layer and the free tropospheric aerosol layers. Nevertheless, according to radiosonde profiles of potential temperature the boundary layer height was below $2 \mathrm{~km}$ (Mattis et al., 2003). One can easily see two maxima, one below $4 \mathrm{~km}$ and the other above $5 \mathrm{~km}$. This enhanced aerosol could be observed up to a height of about $6 \mathrm{~km}$.
These lidar results are in good agreement with the FLEXPART forest fire CO simulations with ECMWF (dotted line) and GFS (solid line) data (Fig. 6b), which also show double maxima at similar altitudes over Leipzig between 1821 UTC on 29 May 2003. Figure 6c shows FLEXPART backward simulation beginning at Leipzig, Germany. It represents the sum of the residence time of the air arriving at the receptor determine on a uniform grid. Further backward calculations suggest that the lower and larger maximum corresponds to parts of the smoke plume which had been over southern Norway two days earlier. The upper and smaller maximum is associated with the remnants of a thin filament which was stretched southwards across Ireland and western France on 25 May (Fig. 5a) and was subsequently advected eastwards, reaching western Germany on 27 May (Fig. 5c). It is also probable that these plumes will have begun to merge by this time with smoke which had been continuing to spread out of Russia directly from the east. The simulated CO tracer concentrations at Leipzig are relatively low but extend over a large altitude range. In the FLEXPART vertical cross section through the latitude at Leipzig (Fig. 5f), Leipzig is close to the edges of the two simulated smoke plumes. The large observed lidar backscatter ratios suggest that in reality Leipzig may have been closer to the center of at least one of the two plumes. 


\section{Conclusions}

In this paper, we investigated the transport of smoke from Russian boreal forest fires from 10 to 31 May, 2003 using the Lagrangian dispersion model, FLEXPART, comparing simulations based on ECMWF and GFS meteorological data.

The transport of the smoke plumes was unique in the sense that, within 17 days, smoke had circumnavigated the globe: perhaps the first time this has been so clearly documented. From the source, smoke crossed the Bering Sea to Alaska, where it was visible in SeaWiFS imagery and then quickly crossed to eastern Canada, where the MODIS Terra satellite witnessed it. It proceeded across the Atlantic to Europe, as captured in a further SeaWiFS image, on its way back to Russia and began to merge over Europe with smoke which had been advected directly out of Russia westwards. By the end of May 2003 the plume had engulfed much of the Northern Hemisphere. The fact that haze plumes from boreal forest fires can circumnavigate the globe and can persist for longer than two weeks has large implications for the radiative heating of the atmosphere (Fiebig et al., 2002). Not accounting for such plumes in climate model simulations or numerical weather predictions may possibly lead to large errors.

FLEXPART simulations based on both ECMWF and GFS data could reproduce much of the fine-scale structure seen in the satellite images with remarkable accuracy, even after the smoke plume had travelled almost around the northern hemisphere. It is not clear from our results which of the two simulations is in better agreement with the observations.

Acknowledgements. We acknowledge ECMWF and the German Weather Service for permitting access to the ECMWF archives and also NCEP for the GFS data. We appreciate the provision of data via the internet by the science teams of MODIS, TOMS and SeaWiFS. This study was funded by the European Commission in the European Research Framework 5 program as part of the PARTS (no. EVK2CT200100112) project and the German Federal Ministry for Education and Research in the Framework of the Atmospheric Research 2000 program as part of the NOXTRAM (07 ATF05) and ATMOFAST (07 ATF08) projects.

Edited by: A. Hofzumahaus

\section{References}

Andreae, M. O.: Biomass burning: Its history, use and distribution and its impact on environmental quality and global climate, in Global Biomass Burning: Atmospheric, Climate, and Biospheric Implications, edited by Levine, J. S., pp. 3-21, MIT Press, Cambridge, Mass, 1991.

Andreae, M. O. and Merlet, P.: Emissions of trace gases and aerosols from biomass burning, Global Biogeochem. Cycles, 15, 955-977, 2001.

Beirle, S., Platt, U., Wenig, M., and Wangner, T.: Weekly cycle of $\mathrm{NO}_{2}$ by GOME measurements: a signature of anthropogenic sources, Atmos. Chem. Phys., 3, 2225-2232, 2003.
Cahoon, D. R., Stocks, B. J, Levine, J. S., Cofer III, W. R., and Pierson, J. M.: Satellite analysis of the severe 1987 forest fires in northern China and southeastern Siberia, J. Geophys. Res., 99, 18 627-18 638, 1994.

Christopher, S., Chou, J., Chang, J., Lin, X., Berendes, T. A., and Welch, R. M.: Shortwave direct radiative forcing of biomass burning aerosols estimated using VIRS and CERES data, Geophys. Res. Lett., 27, 2197-2200, 2000.

Chu, D. A., Kaufman, Y. J., Ichoku, C., Remer, L. A., Tanre, D., and Holben, B. N.: Validation of MODIS aerosols optical depth retrieval over land, Geophys. Res. Lett., 29, 12, doi:10.1029/2001GL013205, 2002.

Cofer, W. R., Winstead, E. L., Stocks, B. J., Goldammer, J. G., and Cahoon, D. R.: Crown fire emissions of $\mathrm{CO}_{2}, \mathrm{CO}, \mathrm{H}_{2}, \mathrm{CH}_{4}$, and TNMHC from dense jack pine boreal forest fire, Geophys. Res. Lett., 25, 3919-3922, 1998.

Conard, S. G. and Ivanova, G. A. : Wildfire in Russian boreal forests - potential impacts of fire regime characteristics on emissions and global carbon estimates, Envir. Pol., 98, 305-313, 1998.

Conard, S. G., Sukhinin, A. I., Stocks, B.J., Cahoon, D. R., Davidenko, E. P., and Ivanova, G. A.: Determining effects of area burned and fire severity on carbon cycling and emissions in Siberia, Climate Change, 55, 197-211, 2002.

Crutzen, P. J.: A discussion of the chemistry of some minor constituents in the stratosphere and troposphere, Pure Appl. Geophys., 106-108, 1385-1399, 1973.

Daniel, J. S. and Solomon, S.: On the climate forcing of carbon monoxide, J. Geophys. Res., 103, 13 249-13 260, 1998.

ECMWF: User Guide to ECMWF Products 2.1, Meteorol. Bull. M3.2, ECMWF, Reading, UK, 1995.

Edwards, D. P., Lamarque, J.-F., Attie, J.-L., Emmons, L. K., Richter, A., Cammas, J.-P., Gille, J. C., Francis, G. L., Deeter, M. N., Warner, J., Ziskin, D. C., Lyjak, L. V., Drummond, J. R., and Burrows, J. P.: Tropospheric ozone over the tropical Atlantic: A satellite perspective, J. Geophys. Res., 108, 4237, doi:10.1029/2002JD002927, 2003.

Emanuel, K. A. and Zivkovic-Rothman, M.: Development and evaluation of a convection scheme for use in climate models, J. Atmos. Sci., 56, 1766-1782, 1999.

Fiebig, M., Petzold, A., Wandinger, U., Wendisch, M., Kiemle, C., Stifter, A., Ebert, M., Rother, T., and Leiterer, U.: Optical closure for an aerosol column: Method, accuracy, and inferable properties applied to a biomass-burning aerosol and its radiative forcing, J. Geophys. Res., 107, 8130, doi:10.1029/2000JD000192, 2002.

Formenti, P., Reiner, T., Wendisch, M., et al.: : STAAARTE-MED 1998 summer airborne measurements over the Aegean Sea, 1, Aerosol particles and trace gases, J. Geophys. Res., 107, 4450, doi:10.1029/2001JD001337, 2002.

Forster, C., Wandinger, U., Wotawa, G., James, P., Mattis, I., Althausen, D., Simmonds, P., O’Doherty, S., Jennings, S., Kleefeld, C., Schnieder, J., Trickl, T., Kreipl, S., Jäger, H., and Stohl, A.: Transport of boreal forest fire emissions from Canada to Europe, J. Geophys. Res., 106, 22 887-22 906, 2001.

Fromm, M., Alfred, J., Hoppel, K., Hornstein, J., Bevilacqua, R., Shettle, E., Servranckx, R., Li, Z., and Stocks, B.: Observations of boreal forest fire smoke in the stratosphere by POAM III, SAGE II, and lidar in 1998, Geophys. Res. Lett., 27, 1407$1410,2000$. 
Fromm, M. D. and Servranckx, R.: Transport of forest fire smoke above the tropopause by supercell convection, Geophys. Res. Lett., 30, 1542, doi: 1029/2002GL016820, 2003.

Galanter, M., Levy II, H., and Carmichael, G. R.: Impacts of biomass burning on tropospheric $\mathrm{CO}, \mathrm{NO}_{\mathrm{x}}$, and $\mathrm{O}_{3}$, J. Geophys. Res., 105, 6633-6653, 2000.

Global Fire Monitoring Center (GFMC): Daily/weekly updates of forest fires in the Russian Federation, http://www.fire. uni-freiburg.de/current/globalfire.htm, 2003.

Gordon, H. R. and Wang M.: Retrieval of water-leaving radiance and aerosol optical thickness over the oceans with SeaWiFS: a preliminary algorithm, Appl. Opt., 33, 443-452, 1994.

Hooker, S. B., Mcclain, C. R., and Holmes, A.: Ocean color imaging - Costal Zone Color Scanner (CZCS) to Sea WiFS, Marine Technology Society Journal, 27, 3-15, SPR, 1993.

Hsu, N. C., Herman, J., Gleason, J., Torres, O., and Seftor, C.: Satellite detection of smoke aerosols over a snow/ice surface by TOMS, Geophys. Res. Lett. 26, 1165-1168, 1999.

IPCC: Climate Change, edited by Nebojsa Nakicenovic and Rob Swart, Cambridge Univ. Press, New York, 2001.

Justice, C. O., Kendall, J. D., Dowty, P. R., and Scholes, R.: Satellite remote sensing of fires during the SAFARI campaign using NOAA advanced very high radiometer data, J. Geophys. Res., 101, 23 851-23 863, 1996.

Kasischke, E. S., Stocks, B. J., Oneill, K., French, N. H., and Bourgeau-Chavez, L. L.: Direct effects of fire on the boreal forest carbon budget, in Biomass burning and its Inter - Relationships with the Climate System, edited by Innes, J. L., Beniston, M., and Verstraete, M. M., pp. 51-68, Kluwer Academic Publishers, Dordrecht, Netherlands, 2000.

Kasischke, E. S. and Bruhwiler, L. P.: Emissions of carbon dioxide, carbon monoxide, and methane from boreal forest fires in 1998, J. Geophys. Res., 108, 8146, doi:10.1029/2001JD000461, 2003.

Kaufman, Y. J., Justice, C. O., Flynn, L. P., Kendall, J. D., Prins, E. M., Giglio, L., Ward, D. E., Menzel, W. P., and Setzer, A. W.: Potential global fire monitoring from EOS-MODIS, J. Geophys. Res., 103, 32 215-32 238, 1998.

Kaufman, Y. J., Ichoku, C., Giglio, L., Korontzi, S., Chu, D. A., Hao, W. M., Li, R.-R., and Justice, C. O.: Fire and smoke observed from Earth Observing System MODIS instrument - products, validation, and operational use, Int. J. Remote Sensing, 24, 1765-1781, 2003.

Lavoue, D. C., Liousse, C., Cachier, H., Stocks, B. J., and Goldammer, J. G.: Modelling of carbonaceous particles emitted by boreal and temperate wildfires at northern latitudes, J. Geophys. Res., 105, 26 871-26890, 2000.

Logan, J. A., Prather, M. J., Wofsy, S. C., and McElroy, M. B.: Tropospheric chemistry: A global perspective, J. Geophys. Res., 86, 7210-7254, 1981.

Mattis, I., Ansmann, A., Wandinger, U., and Müller, D.: Unexpectedly high aerosol load in the free troposphere over Central Europe in spring/summer 2003, Geophys. Res. Lett., 30, 2178, doi:10.1029/2003GL018442, 2003.

Platt, U.: Differential optical absorption spectroscopy (DOAS), in air monitoring by spectroscopic techniques, M. W. Sigrist (Ed.), Chemical Analysis Series vol. 127, John Wiley, New York, 1994.
Remer, L. A., Tanre, D., Kaufman, Y. J., Ichoku, C., Mattoo, S., Levy, R., Chu, D. A., Holben, B. N., Dubovik, O., Ahmad, Z., Smirnov, A., Martins, J. V., and Li, R.-R.: Validation of MODIS aerosol retrieval over ocean. Geophys. Res. Lett. 29, 12, doi:10.1029/2001GL013204, 2002.

Seinfeld, J. H. and Pandis, S. N.: Atmospheric Chemistry and Physics, 1326pp., John Wiley, Inc., New York, 1998.

Shvidenko, A. Z., and Nilsson, S.: Fire and the carbon budget of Russian forest, in Fire, Climate Change, and Carbon Cycling in the Boreal Forest, edited by E. S. Kasischke, Ecol. Stud., 138, 289-311, 2000

Shvidenko, A. and Goldammer, J. G.: Fire situation in Russia, International Forst Fire News, 24, 41-59, 2001.

Soja, A. J., Sukhinin, A. I., Cahoon, D. R., Shugart, H. H., and Stackhouse, P. W.; AVHRR-derived fire frequency, distribution and area burned in Siberia, Int. J. Remote Sensing, 25, 19391960, 2004.

Spichtinger, N., Wenig, M., James, P., Wagner, T., Platt, U., and Stohl, A.: Satellite detection of a continental-scale plume of nitrogen oxides from boreal forest fires, Geophys. Res. Lett., 28, 4579-4583, 2001.

Stohl, A., Hittenberger, M., and Wotawa, G.: Validation of the Lagrangian particle dispersion model FLEXPART against large scale tracer experiment data, Atmos. Environ., 24, 4245-4264, 1998.

Stohl, A. and Trickl, T.: A textbook example of long-range transport: Simultaneous observation of ozone maxima of stratospheric and North American origin in the free troposphere over Europe, J. Geophys. Res., 104, 30 445-30 462, 1999.

Stohl, A. and Thomson, D. J.: A density correction for Lagrangian particle dispersion models, Boundary-Layer Meteorol., 90, 155167, 1999.

Stohl, A.: A one-year Lagrangian climatology of airstreams in the northern hemisphere troposphere and lowermost stratosphere, J. Geophys. Res., 106, 7263-7279, 2001.

Stohl, A., Eckhardt, S., Forster, C., James, P., and Spichtinger, N.: On the pathways and timescales of intercontinental air pollution transport, J. Geophys. Res., 107, 4684, doi:10.1029/2001JD001396, 2002.

Valendick, E. N.: Ecological aspects of forest fires in Siberia, Sib. Ecol. J., 1, 1-8, 1996.

Wandinger, U., Bockmann, C., Mathias, V., et al.: Optical and microphysical characterization of biomass- burning and industrial-pollution aerosols from multiwavelength lidar and aircraft measurements, J. Geophys. Res., 107, 8125, doi:10.1029/2000JD000202, 2002.

Wotawa, G. and Trainer, M.: The influence of Canadian forest fires on pollutant concentrations in the United States, Science, 288, 324-328, 2000.

Yoshizumi, K., Kato, S., Streets, D. G., Tsai, Y. N., Shvidenko, A., Nilsson, S., McCallum, I., Minko, N. P., Abushenko, N., Altyntsev, D., and Khodzer, T. V.: Boreal forest fires in Siberia in 1998: Estimation of area burned and emissions of pollutants by advanced very high resolution radiometer satellite data, J. Geophys. Res., 107, 4745, doi:10.1029/2001JD001078, 2002. 